University of Maryland Francis King Carey School of Law

DigitalCommons@UM Carey Law

\title{
Platform Neutrality: Enhancing Freedom of Expression in Spheres of Private Power
}

Frank A. Pasquale

University of Maryland Francis King Carey School of Law, fpasquale@law.umaryland.edu

Follow this and additional works at: https://digitalcommons.law.umaryland.edu/fac_pubs

Part of the First Amendment Commons, and the Internet Law Commons

\section{Digital Commons Citation}

Pasquale, Frank A., "Platform Neutrality: Enhancing Freedom of Expression in Spheres of Private Power" (2016). Faculty Scholarship. 1603.

https://digitalcommons.law.umaryland.edu/fac_pubs/1603

This Article is brought to you for free and open access by the Francis King Carey School of Law Faculty at DigitalCommons@UM Carey Law. It has been accepted for inclusion in Faculty Scholarship by an authorized administrator of DigitalCommons@UM Carey Law. For more information, please contact smccarty@law.umaryland.edu. 


\title{
Platform Neutrality: Enhancing Freedom of Expression in Spheres of Private Power
}

\begin{abstract}
Frank Pasquale*
Troubling patterns of suppressed speech have emerged on the corporate internet. A large platform may marginalize (or entirely block) potential connections between audiences and speakers. Consumer protection concerns arise, for platforms may be marketing themselves as open, comprehensive, and unbiased, when they are in fact closed, partial, and self-serving. Responding to protests, the accused platform either asserts a right to craft the information environment it desires, or abjures responsibility, claiming to merely reflect the desires and preferences of its user base. Such responses betray an opportunistic commercialism at odds with the platforms' touted social missions. Large platforms should be developing (and holding themselves to) more ambitious standards for promoting expression online, rather than warring against privacy, competition, and consumer protection laws. These regulations enable a more vibrant public sphere. They also defuse the twin specters of monopolization and total surveillance, which are grave threats to freedom of expression.
\end{abstract}

\section{INTRODUCTION}

Are powerful internet companies censoring speech? From activists angry at Apple to protesters snubbed by Twitter, confrontations are taking on a familiar pattern. A large platform marginalizes (or entirely blocks) potential connections between speakers and audiences. Responding to protests, the company either asserts its own right to craft the information environment it desires, or abjures responsibility, claiming to merely reflect the desires and preferences of its user base.

* Professor of Law, University of Maryland Francis King Carey School of Law. 
Those who feel censored appeal to legislators, judges, or the court of public opinion. Some claim that they have been denied due process. Others decry monopolization. There are claims of discrimination, or subtle bias, hidden in complex software that is rarely (if ever) analyzed by entities independent of the companies that run it. ${ }^{1}$ Consumer protection concerns also arise, for platforms may be marketing themselves as open, comprehensive, and unbiased, when they are in fact closed, partial, and self-serving. ${ }^{2}$

To defend themselves, some platforms deploy constitutional arguments against regulation of what they say, which constitutes most of what the firms do. Legal scholars have, in turn, formulated more general theories of corporate speech in industries dependent on models, algorithms, and largely automated arrangements of information. ${ }^{3}$ These projects are important and deserve attention from legislators, judges, and regulators. But the pressure to analogize current technologies to past ones in order to apply precedent can occlude the degree to which some new media are fundamentally, qualitatively distinct from past ones. Therefore, theories of the social and political aspects of internet platforms in an era of surveillance capitalism should inform both communications and legal scholarship. ${ }^{4}$ Social theory is an especially important aspect of theoretical inquiry in law when, as Julie Cohen notes elsewhere in this volume, extant regulatory models appear increasingly outdated. ${ }^{5}$

Social theory can also guide regulators as they resolve (or render irrelevant) a basic tension that has vexed communications law: whether internet platforms are better characterized as enablers of communication (conduits), or as embodying content itself. In the United States, judicial sympathy toward the idea of corporate rights has led to decisions affirming for-profit platforms' selection and arrangement of information as not merely copyrightable, but also a form

1 On the secrecy of the underlying code and much data, see Frank Pasquale, The Black Box Society (2015).

2 Scholars were warning about this problem for years before it became a major public concern. See, e.g., Lucas Introna \& Helen Nissenbaum, Shaping the Web: Why the Politics of Search Engines Matters, 16 Info. Soc'y 169 (2000).

3 See, e.g., Anupam Chander \& Uyen P. Le, Free Speech, 100 Iowa L. REv. 501 (2015); Andrew Tutt, The New Speech, 41 Hastings Const. L.Q. 235 (2014); Rebecca Tushnet, Power Without Responsibility: Intermediaries and the First Amendment, 76 Geo. Wash. L. Rev. 986 (2008); Christopher S. Yoo, Free Speech and the Myth of the Internet as an Unintermediated Experience, 78 GEo. WASH. L. REv. 697 (2010).

4 Shoshana Zuboff, Big Other: Surveillance Capitalism and the Prospects of an Information Civilization, 30 J. INFo. TECH. 75 (2015).

5 Julie E. Cohen, The Regulatory State in the Information Age, 17 Theoretical INQUIRIES L. 369 (2016). 
of free speech. ${ }^{6}$ In Europe, free expression rights have been better cabined to speech by individual human beings, rather than "corporate persons" or software. ${ }^{7}$

This basic divergence in values helps explain a number of policy differences between the United States and the European Union, in areas ranging from privacy to antitrust to industrial policy. The U.S. approach is at its core neoliberal, premised on accelerating capital acquisition by asymmetrically disabling some forms of state power (such as consumer protection) and entrenching others (such as the protection of corporate trade secrets). As befits a more mixed economy, the EU approach is nuanced and variegated. But neither rests on a broader normative theory of what a well-ordered digital sphere of freedom of expression would look like.

This Article aims to clear some ground to enable the development of such a theory, by examining the relationship between free expression and regulation on the internet. Many attorneys believe there is a tension between regulation and free expression. But in fact, when antitrust or competition law, consumer protection regulation, and privacy protections apply to very large internet platforms, they are as apt to promote freedom of expression as to limit it. Such laws are critical tools to ensure "platform neutrality," a principle whose flexibility matches the protean nature of today's online environment. The core idea of neutrality is to prevent massive intermediaries from distorting either private commerce or the public sphere simply by virtue of their size, network power, or surveillance capacities. As the French Conseil National du Numerique has observed, "[ $\mathrm{t}]$ he goals behind the neutrality principle should ... be factored into the development of digital platforms: while extremely useful and innovative, their growth must not be allowed to hamper the use of Internet as a forum for creation, free expression and the exchange of ideas." 8

6 See, e.g., Zhang v. Baidu.com Inc., 2014 WL 1282730, at *6 (SDNY 2014) ("[A]llowing Plaintiffs to sue Baidu for what are in essence editorial judgments about which political ideas to promote would run afoul of the First Amendment.").

7 See, e.g., Case C-131/12, Google Spain SL, Google Inc. v. Agencia Españiola de Protección de Datos, Mario Costeja González, 2014 EUR-Lex 62012CJ013 (May 13, 2014), http://eur-lex.europa.eu/legal-content/EN/TXT/PDF/?uri=CELE $\mathrm{X}$ :62012CJ0131\&from=EN; Frank Pasquale, Reforming the Law of Reputation, 47 Loy. U. CHI. L.J. 515 (2015) (discussing the implications of the right to be forgotten in particular and the policies behind Europe's General Data Protection Regulation in general).

8 Conseil National Numerique, Platform Neutrality: Building an Open and Sustainable Digital Environment (2014), http://www.cnnumerique.fr/wpcontent/uploads/2014/06/PlatformNeutrality_VA.pdf; Axelle Lemair, Which Digital Strategy for France and Europe in an Age of Disruption?, Lecture at 
In the wake of recent accusations of news suppression at Facebook, even U.S. conservatives appear open to some version of these values. ${ }^{9}$

It is wrong to treat massive internet intermediaries as vulnerable media always in danger of being suborned by the state, as Part I shows. Viewing intermediaries as digital utilities opens up new opportunities for regulation in the public interest, as Part II shows. This regulation may crimp the "free expression" of "corporate persons," but is necessary for fair opportunities at expression (or even understanding of the social world) by human persons generally. The Article concludes with reflections on how platform neutrality can inform future regulatory initiatives directed toward new media.

\section{Content or Conduit: Intermediaries' Convenient Identity CRISIS}

Telecommunications infrastructure has enabled enormous advances in expression. ${ }^{10}$ The critical free expression at stake in governmental regulation of such services is that of their users, rather than that of the platforms themselves. ${ }^{11}$ This emphasis prevents carriers from, say, deploying opportunistic assertions of free expression protections to justify denials of service to businesses and persons of whom they disapprove. It also helps immunize carriers from responsibility for what customers say while using their services. ${ }^{12}$ The phone company can

the London School of Economics Public Event, London, U.K. (Mar. 20, 2015), http://www.lse.ac.uk/publicEvents/events/2015/03/20150320t1800vWT.aspx.

9 Michael Nunez, Senate GOP Launches Inquiry into Facebook's News Curation, Gizmodo (May 10, 2016), http://gizmodo.com/senate-gop-launches-inquiry-intofacebook-s-news-curati-1775767018 (based on news reports that Facebook news curators systematically suppressed conservative news). This situation belied a common defense of unfettered corporate speech rights in the online context namely, that the algorithms personalizing feeds are too complex for outsiders to assess. For further critiques of that idea, see Frank Pasquale, Bittersweet Mysteries of Machine Learning, London Sch. of Econ. Media Pol'y Blog (Feb. 3, 2016), http://blogs.lse.ac.uk/mediapolicyproject/2016/02/05/bittersweet-mysteries-ofmachine-learning-a-provocation/.

10 Jack Balkin, Digital Speech and Democratic Culture: A Theory of Freedom of Expression for the Information Society, 79 N.Y.U. L. REv. 1 (2004).

11 Nicholas Bramble, Ill Telecommunications: How Internet Infrastructure Providers Lose First Amendment Protection, 17 Mich. Telecomm. \& Tech. L. Rev. 67 (2010); Christopher Yoo, Architectural Censorship and the FCC, 78 S. CAL. L. Rev. 669 (2005).

12 Tim Wu, Has AT\&T Lost Its Mind, Slate Mag. (Jan. 16, 2008), http://www.slate. com/articles/news_and_politics/jurisprudence/2008/01/has_att_lost_its_mind.html. 
be forced by government to extend service to the home of someone likely to defame others; but even if that person uses the phone to make defamatory comments, those harmed cannot try to hold the carrier responsible. ${ }^{13}$ It is a common carrier, under Title II of the Federal Communications Act, ${ }^{14}$ and must take all comers who can pay reasonable, nondiscriminatory fees.

The same delicate balance persisted, albeit in a diluted form, in the case of cable networks. When challenging must-carry rules on First Amendment grounds in the United States, ${ }^{15}$ they had a better case than the phone companies. One can, in principle, imagine a cable carrier with a very specific ideology and aspiration to express it via selection of channels. Nevertheless, in Turner v. FCC, the Supreme Court held that must-carry rules could apply to cable networks as well. ${ }^{16}$

Indeed, courts have permitted certain forms of government regulation of the press even for entities that clearly produced content, such as radio stations, or broadcasters (which may only be one of hundreds of channels provided by a cable carrier). The Federal Communications Commission (FCC) imposed "equal time" regulations on broadcasters, and the Supreme Court unanimously affirmed the regulation as constitutional. ${ }^{17}$ However, for other media, government intervention was more limited. For instance, in Miami Herald v. Tornillo, a state "right of reply" statute (giving those criticized in a newspaper a chance to have their own replies printed in the same newspaper) was rejected by the Court as a violation of the First Amendment. ${ }^{18}$

There may seem to be a conflict between Miami Herald's affordance of very strong First Amendment protection to a newspaper, and Red Lion's

13 Federal Communications Act, 47 U.S.C. $§ 202$ (2012).

14 Id. $\S 201$.

15 Turner Broad. Sys., Inc. v. FCC, 512 U.S. 622 (1994); see also Turner Broad. Sys., Inc. v. FCC, 520 U.S. 180 (1997).

16 Turner, 520 U.S. at 185 . Carrying three mandatory channels was a small burden to a cable company, and the burden was outweighed by the furthering of government interests in "(1) preserving the benefits of free, over-the-air local broadcast television, (2) promoting the widespread dissemination of information from a multiplicity of sources, and (3) promoting fair competition in the market for television programming." Id. at 189-90.

17 Red Lion Broad. Co. v. FCC, 395 U.S. 367 (1967). For more on the legacy of Red Lion, see Dawn Nunziato, Virtual Freedom: Net Neutrality and Free SPEech in the Internet Age (2009).

18 Miami Herald v. Tornillo, 418 U.S. 241, 258 (1974) ("It has yet to be demonstrated how governmental regulation of this crucial [editorial] process can be exercised consistent with First Amendment guarantees of a free press as they have evolved to this time."). 
affirmation of regulation of radio stations. ${ }^{19}$ In Red Lion, the U.S. Supreme Court unanimously affirmed the FCC's decision to require broadcasters to grant political candidates they criticized some "right of reply." This "fairness doctrine" was meant to assure that the power of broadcasters would be exercised in the public interest, rather than simply reflect the political views of their owners. The Court permitted this regulation of the airwaves in Red Lion, by reasoning that broadcasters deserve less protection because of the scarcity of channels, and a history of governmental regulation in the area. Of course, the "history of regulation" rationale begs the question of why the FCC was allowed to regulate the airwaves in the first place. A more plausible approach focuses on the pervasiveness and scarcity of the media involved. Newspapers generally were delivered only to paid subscribers, and anyone (with enough money) could start one. ${ }^{20}$ Television and radio stations broadcast indiscriminately (within their range), and had to be licensed by the FCC.

Internet access has raised new questions for both the Supreme Court and regulators. In the 1997 case Reno v. American Civil Liberties Union, ${ }^{21}$ the Supreme Court struck down anti-indecency elements of the Communications Decency Act (CDA), ${ }^{22}$ aimed at the regulation of pornography. Though the Court had upheld anti-indecency regulation in prior cases involving broadcast networks, it found the CDA's provisions too broadly drawn. ${ }^{23}$ More importantly for our purposes, it characterized the Internet as a medium far less invasive and more open than radio or broadcast media:

[W]e [have] observed that "[e]ach medium of expression . . may present its own problems." Thus, some of our cases have recognized special justifications for regulation of the broadcast media that are not applicable to other speakers. ... In these cases, the Court relied on the history of extensive Government regulation of the broadcast medium, ... the scarcity of available frequencies at its inception . . . and its "invasive" nature. ...

19 See, e.g., William W. Van Alstyne, The Möbius Strip of the First Amendment: Perspectives on Red Lion, 29 S.C. L. Rev. 539, 544 (1978).

20 Jerome Barron, Access Reconsidered, 76 Geo. WASH. L. Rev. 826 (2008); see also Yochai Benkler, The Wealth of Networks: How Social Production Transforms Markets and Freedom (2006) (on the cost of printing press, etc.).

21 Reno v. Am. Civil Liberties Union, 521 U.S. 844 (1997).

22 Communications Decency Act, Pub. L. No. 104-104, 110 Stat. 133 (1996) (codified as amended at scattered sections of 47 U.S.C.).

23 The CDA had prohibited "the knowing transmission of obscene or indecent messages to any recipient under 18 years of age." Reno, 521 U.S. at 859 (citing 47 U.S.C. § 223 (1994 ed., Supp. II)). 
Those factors are not present in cyberspace. Neither before nor after the enactment of the CDA have the vast democratic forums of the Internet been subject to the type of government supervision and regulation that has attended the broadcast industry. Moreover, the Internet is not as "invasive" as radio or television. ${ }^{24}$

Even at the time Reno was decided, Justices O'Connor and Rehnquist worried about its continuing relevance. In a separate opinion (concurring in part and dissenting in part), they urged Congress to consider future lawmaking premised on new technological development that could more effectively "zone" parts of the internet for children only. ${ }^{25}$

Fortunately, the Reno case can be read as only applying to regulation targeting the internet as a whole, and not necessarily as an all-purpose quashing of any effort to qualify the level of First Amendment scrutiny that should be applied to important firms or sectors within the internet. The internet in general may "provide relatively unlimited, low-cost capacity for communication of all kinds," ${ }^{26}$ but the dominant search engines and social networks within it meticulously exercise control over search results and newsfeeds. Moreover, the Reno case even appears dated in the context of broadband internet access. In the early 2000 s, the FCC voted to largely deregulate internet services, reasoning that a relatively competitive market in access would discipline carriers and give users ample opportunities to switch to congenial networks. ${ }^{27}$ But by 2012, a decade of evidence demonstrated the opposite: both fixed and mobile broadband services were subject to significant concentration and indifference to important consumer and public concerns. ${ }^{28}$

24 Id. at 868-69.

25 A similar concern arises today in the context of French authorities' efforts to apply the "right to be forgotten" to Google sites accessed in France (such as Google. com), rather than simply to the site operated by Google's French subsidiary (Google.fr). Google characterizes the efforts as a form of censorship that would allow one country to dictate to the world its views on the permissibility of publishing certain links in response to certain name-based queries. However, geo-blocking could address the issue by applying the decision to sites accessed in France, rather than simply applying it to Google.fr (a "remedy" that simply invites widespread usage of the Google.com site). See Julia Powles, Right to Be Forgotten: Swiss Cheese Internet, or Database of Ruin?, Guardian, Aug. 1, 2015, http://www.theguardian.com/technology/2015/aug/01/right-to-beforgotten-google-swiss-cheese-internet-database-of-ruin.

26 Reno, 521 U.S. at 870.

27 Nat'l Cable \& Telecomm. Ass'n v. Brand X Internet Serv., 545 U.S. 967 (2005).

28 Susan Crawford, Captive Audience: The Telecom Industry and Monopoly Power in the New Gilded Age (2012). 
Reno was a double victory for internet firms. While striking down the anti-indecency provisions of the CDA, the Court let stand its Section 230, a veritable Magna Carta of corporate impunity with respect to causes of action like defamation, privacy violations, and business torts. ${ }^{29}$ The year after the CDA passed, the Digital Millennium Copyright Act (DMCA) of $1998^{30}$ afforded immunities to intermediaries for intellectual property infringement enabled by their networks. As long as they operated "notice and takedown" procedures to respond to complaints of intellectual property infringement via uploads or links provided by their sites, they could avoid liability. ${ }^{31}$

Not all countries have laws like the CDA and DMCA. ${ }^{32}$ Nevertheless, in the many forums that have tried to call Google, Facebook, Amazon, and other firms to account, a fundamentally American-exceptionalist legal logic based on the two laws has informed these leading internet intermediaries' efforts to deflect liability. When intellectual property or defamation claims arise, they emphasize their role as mere conduits, reflecting the preferences and serving the interests of users. But when classic business tort or privacy claims arise, intermediaries argue that they are speakers, their selection and arrangement of information a type of activity best protected as freedom of expression. ${ }^{33}$

Thus, Google has shifted its self-characterization as content-provider or conduit opportunistically. ${ }^{34}$ For example, due to a number of anti-Semites'

29 Michael L. Rustad \& Thomas H. Koenig, Rebooting Cybertort Law, 80 WAsH. L. Rev. 335, 364 (2005); Felix T. Wu, Collateral Censorship and the Limits of Intermediary Immunity, 87 Notre Dame L. Rev. 293 (2011).

30 Digital Millennium Copyright Act, Pub. L. No. 105-304, 112 Stat. 2860 (1998) (codified as amended in scattered sections of 17 U.S.C.).

31 Corey Omer, Intermediary Liability for Harmful Speech: Lessons from Abroad, 28 Harv. J.L. \& Tech. 290 (2014).

32 Id. For example, many countries require search engines to take down links that they would be under no obligation to remove in the United States. PASQUALE, supra note 1, at 198 ("Germany, Argentina, and Japan, for example, have all required Google to alter certain search results that defame individuals or mislead users."). However, trade agreements now being negotiated may end up further internationalizing policies of immunity and impunity for intermediaries.

33 See Tansy Woan, Searching for an Answer: Can Google Legally Manipulate Search Engine Results?, 16 U. PA. J. Bus. L. 294 (2013); Tim Wu, Machine Speech, 161 U. PA. L. Rev. 1495 (2013).

34 Noam Cohen, Professor Makes the Case That Google Is a Publisher, N.Y. Times, May 20, 2012, http://www.nytimes.com/2012/05/21/business/media/ eugene-volokh-ucla-professor-makes-a-case-for-google-as-publisher. html?pagewanted=all\&_r=0.html ("Is Google search an intermediary like the phone company - simply connecting people with the information they seek? 
efforts to manipulate search rankings, a Holocaust denial site routinely appeared in the top ten results for the query "Jew." ${ }^{35}$ In response to complaints from the Anti-Defamation League, Google added a headline titled, "An explanation of our search results" to the top of the page..$^{36}$ The linked webpage explained the reasons why the anti-Semitic site appeared so high in the relevant rankings and distanced Google from the results. ${ }^{37}$ During this controversy, and in many subsequent instances, Google presented itself as little more than a cultural voting booth, a transmitter of popular preference as processed through algorithms with no obligation to reflect social values. Just as the U.S. Supreme Court has frequently protected repulsive and offensive speech as the "price" of a neutrally, objectively applied First Amendment, Google claimed that it must accept that an anti-Semitic site could rise to the top of search results on the basis of neutral signals used to rank sites generally. But in many other disputes, Google claims an absolute right to knock any site off any search result page it generates..$^{38}$ That is the natural, if ironic, logic of its "free speech" case against antitrust liability for favoring its own services and demoting competitors in search results. ${ }^{39}$ Note that such a "free expression" rationale would not simply

Or is Google search a publisher, like a newspaper, which provides only the information that it sees fit and is protected by the First Amendment?").

35 The site, JEw WATCH, http://www.jewwatch.com/ (last visited Feb. 1, 2016), is an obvious hate site. For further discussion, see Jonathan Zittrain, Love the Processor, Hate the Process, Harv. Law Sch. Chair Lecture, Cambridge, Mass. (Apr. 2, 2015), https://cyber.law.harvard.edu/events/2015/04/Zittrain.

36 See Google Search Ranking of Hate Sites Not Intentional, Anti-Defamation LEAGUE, http://www.adl.org/rumors/google_search_rumors.asp (last updated Apr. 22, 2004):

The ranking of Jewwatch and other hate sites is in no way due to a conscious choice by Google, but solely is a result of this automated system of ranking. ... The longevity of ownership, the way articles are posted to it, the links to and from the site, and the structure of the site itself all increase the ranking of [the anti-Semitic site] within the Google formula.

37 Google Responds to ADL: Google Explains Its Search Results, Anti-Defamation LEAGUE, http://archive.adl.org/internet/google_explanation.html (last visited Feb. 1, 2016):

If you recently used Google to search for the word "Jew," you may have seen results that were very disturbing. We assure you that the views expressed by the sites in your results are not in any way endorsed by Google. We'd like to explain why you're seeing these results when you conduct this search.

38 Eugene Volokh \& Donald Falk, First Amendment Protection for Search Engine Search Results, 8 J.L. Econ. \& PoL'y 883 (2012); see also Woan, supra note 33, at 316-24.

39 Volokh \& Falk, supra note 38. 
allow Google to decide, say, how to present results for political candidates or culturally sensitive issues ${ }^{40}$ Rather, its extraordinary over-inclusiveness would also privilege the firm's ability to hide results leading to startups founded by its ex-employees, or rival firms.

Large technology platforms' strategic, opportunistic, and contradictory self-characterizations take advantage of the siloed nature of legal disputes. Specialization obscures the big picture as individual disputes come to judges and regulators prepackaged as "free expression," "intellectual property," or "privacy" disputes. Cyberlaw scholars can unintentionally contribute to the extraordinary power of internet firms by adopting a similar logic of specialization, and losing sight of the larger picture. Google, for instance, has won key cases in copyright, trademark, and antitrust; key immunities in the context of free expression defenses; and has avoided classification as a "consumer reporting agency" under the Fair Credit Reporting Act. ${ }^{41}$ Any particular outcome may well have been advisable as a matter of law and/or policy, considered alone. But what happens when a critical mass of close cases combines with network effects to give a few firms extraordinary power over our information about (and even interpretation of) events? A legal system incapable of answering (or even contemplating) such a question has little chance of constructively channeling the development of new technologies. ${ }^{42}$

These opportunistic shifts in self-characterization have also made U.S. internet intermediary law a major barrier to accountability online, and threaten

40 These decisions could be very important. Robert Epstein, How Google Could Rig the 2016 Election, Politico, Aug. 19, 2015, at http://www.politico.com/ magazine/story/2015/08/how-google-could-rig-the-2016-election-121548 (popularizing Epstein's past, peer-reviewed research on the persuasive impact of undetectable biases in search engines that are either mandated by managers, coded by engineers, or arise in an emergent fashion from the interplay of user data and algorithmic ordering of information).

41 Fair Credit Reporting Act, 15 U.S.C. $\$ 1681$ (2012); Perfect 10, Inc. v. Amazon. com, Inc., 508 F.3d 1146 (9th Cir. 2007) (copyright); Langdon v. Google, Inc., 474 F. Supp. 2d 622 (D. Del. 2007) (First Amendment); Eric Goldman, Google Defeats Trademark Challenge to Its AdWords Service, ForBEs, Oct. 22, 2012, http://www.forbes.com/sites/ericgoldman/2012/10/22/google-defeats-trademarkchallenge-to-its-adwords-service/\#218564e1270d (summarizing trademark cases); Claire Cain Miller \& Mark Scott, Google Settles Its European Antitrust Case: Critics Remain, N.Y. Times, Feb. 5, 2014, http://www.nytimes.com/2014/02/06/ technology/google-reaches-tentative-antitrust-settlement-with-european-union. html.

42 For a general account of the problem of channeling technology through law, see Laurence Tribe, Channeling Tech Through Law (1973). 
to put intermediaries above the law globally in an era of domestic-lawdisplacing trade agreements. ${ }^{43}$ Following recent work connecting the transfer pricing of intellectual property (where firms have incentives to minimize the value of their IP) to damages claims in IP litigation (where the incentives are to maximize valuation) ${ }_{,}^{4}$ policymakers could refuse to allow intermediaries to have it both ways, forcing them to assume the rights and responsibilities of content-provider or conduit. Such a development would be fairer than current trends, which allow many intermediaries to enjoy the rights of each and responsibilities of neither.

\section{How Regulation Can Promote Speech Online}

Online platforms often characterize their own selection and arrangement of materials, and assistance in helping others' search for materials of interest, as a form of speech. However tempting the metaphor of "search as speech" may be, courts must avoid forcing a vast, sprawling array of human activities into a Procrustean bed of "speech." Otherwise, worthwhile initiatives for reform may be snuffed out before they can even be tried.

\section{A. Must-Carry Rules}

Consider, for instance, Canadian legal scholar Jennifer Chandler's proposed idea of a "right to reach an audience" through dominant search engines ${ }^{45}$ She has argued that the search engine has an obligation, thanks to its dominant position and storage capacities, to index all sites publicly available on the web. ${ }^{46}$ Chandler's idea looks backwards (at precedents like "must-carry"

43 Anupam Chander \& Uyen P. Le, Data Nationalism, 64 EMORY L.J. 677 (2015) (characterizing this development as positive).

44 Andrew Blair-Stanek, Intellectual Property Law Solutions to Tax Avoidance, 62 UCLA L. REv. 2 (2015).

45 Jennifer A. Chandler, A Right to Reach an Audience: An Approach to Intermediary Bias on the Internet, 35 Hofstra L. Rev. 1095 (2007). The Canadian provenance of the proposal is particularly of interest thanks to how many large technology platforms are based in the United States. Without some degree of national control over international firms, the prospect of digital colonization is a clear and present danger. See also Lisa Austin, Technological Tattletales and Constitutional Black Holes: Communications Intermediaries and Constitutional Constraints, 17 Theoretical Inquiries L. 451 (2016).

46 In a series of copyright disputes, Google had argued that it should receive a special dispensation from intellectual property laws so that it could provide and archive, backup copy, and index the web and the world's books. Mary 
rules for cable networks) and could be carried forwards: from a minimalist aspect of net neutrality, to a minor "indexing duty" as an aspect of search neutrality, to an aspect of app neutrality. ${ }^{47} \mathrm{~A}$ presumption of inclusion for those running the app stores and software for dominant phones, like Apple (or GooglePlay, which services Android Phones), could provide a level playing field for unpopular or unprofitable speech while barely affecting the functioning of large platforms.

For deregulationist digerati, the idea of pushing neutrality beyond the "pipes" of the internet, to hardware, critical software, dominant search engines, social networks, and apps, may seem like an impulse for fairness run amok. However, networked technology is often more prone to concentrate power than it is to diffuse it, and when such concentrations of power occur, law must respond to them. ${ }^{48}$ Consider the rise of "WeChat" in China, on a "one app to rule them all" model. ${ }^{49}$ It is primarily a messaging and chat app. But as venture capitalist Connie Chan observes, "WeChat shows what it's like to be both a platform and a mobile portal." ${ }^{50}$ It is easy to book a restaurant reservation, or a doctor, all within the app, as these screenshots captured by Chan show:

Sue Coleman, President of the Univ. of Michigan, Address to the Professional/ Scholarly Publishing Division of the Ass'n of Am. Publishers (Feb. 6, 2006) (talking about preservation and Google Books); Mary Sue Coleman, Opinion, Riches We Must Share..., WASH. Post, Oct. 22, 2005, http://www.washingtonpost. com/wp-dyn/content/article/2005/10/21/AR2005102101451.html. If it deserves exemption from copyright laws to pursue that goal, it should also accept some obligations tailored to the same aim, pursuant to other forms of regulation.

47 Jonathan Zittrain has observed that an FCC Inquiry may foreshadow app neutrality concerns. See Jonathan Zittrain, Net Neutrality: The FCC Takes Back the Ball, ConCURRING Opinions (Sept. 7, 2010, 11:02 AM), http://www.concurringopinions. com/archives/2010/09/net-neutrality-the-fcc-takes-back-the-ball.html ("[M]aybe app neutrality would make us worry less about network discrimination, or net neutrality could still permit app discrimination.").

48 Alexander Galloway, Protocol (2004); David Golumbia, The Culture of Computation (2009).

49 Connie Chan, When One App Rules Them All: The Case of WeChat and Mobile in China, Andreessen Horowitz (Aug. 6, 2015), http://a16z.com/2015/08/06/ wechat-china-mobile-first/.

$50 \quad I d$. 


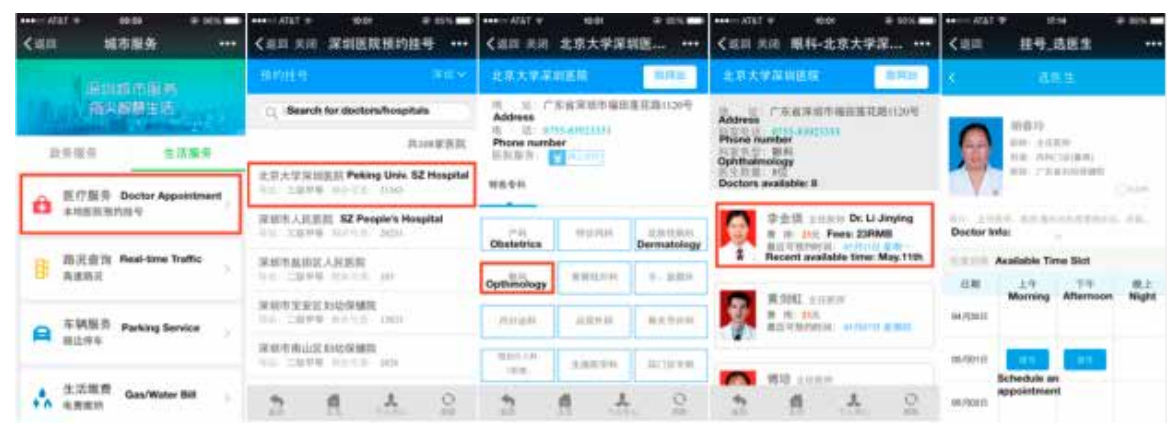

Chan calls WeChat a "kingmaker" for both content and commerce exactly the characterization Alexander Halavais chose for Google in his prescient work Search Engine Society in 2008. ${ }^{51}$ To the extent that it attracts a massive user base to become a dominant intermediary in varied areas of content and commerce, it should attract the same scrutiny originally aimed at intermediaries in movements for net and search neutrality. And even in the very narrow field of "doctor search," rules are common and largely commendable. ${ }^{52}$

The fact that a consumer could, in principle, search for doctors or restaurants in either WeChat or Google or their insurer's website, may seem to diminish the importance of rules of fair treatment binding on any particular platform. But in an age of social acceleration, most users are either not inclined (or lack the time) to make a leisurely choice of what app or search engine (or other intermediary) will best guide them toward what they want. ${ }^{53}$ Leading platforms reign, and tip into dominance at very rapid speed. ${ }^{54}$

Platforms may protest, claiming that they should be treated no differently than a "brick-and-mortar" retailer like Wal-Mart. Few advocate that it be required to stock certain volumes of books, or products. But this misunderstands the difference between digital and physical sales. Executives who brag to

51 Alexander Halavais, Search Engine Society (2008).

52 For documentation of regulation here, see Kristin Madison, The Law and Policy of Health Care Quality Reporting, 31 CampBell L. Rev. 215 (2009); Ann Marie Marciarille, 'How's My Doctoring?' Patient Feedback's Role in Assessing Physician Quality, 14 DePaul J. Health Care L. 361 (2012); and Frank Pasquale, Reputation Regulation, in The Offensive Internet 107 (Saul Levmore \& Martha Nussbaum eds., 2010).

53 Social acceleration is impressively documented in several recent sociological works. See Hartmut Rosa, Social Acceleration: A New Theory of Modernity (2013); Judy Wajcman, Pressed for Time: The Acceleration of Life Under Digital Capitalism (2014).

54 PASQUAle, supra note 1, at 82 (discussing mechanisms of self-reinforcing digital dominance). 
shareholders about a "long tail" of endlessly diverse online content can't turn around and tell governmental authorities that they must jealously guard limited space..$^{55}$ For the largest internet-based companies, an app will take up a tiny fraction of their overall storage and communications capacity. To the extent that the cost is nontrivial, it can be shifted to the app demanding inclusion (plus a reasonable rate of return for the dominant app seller to compensate for the inconvenience). To make the internet a level playing field, dominant companies need to start recognizing the utility-like aspects of their role, and to shoulder some burdens (rather than just pocketing the benefits) of serving as an infrastructure of free expression. ${ }^{56}$

The "long tail" aspect of digital megaplatforms neatly reverses the classic "abundance" rationale for deregulation. In communications law 1.0, agencies invoked "spectrum scarcity" to justify interventions designed to bring some order to, say, the airwaves. ${ }^{57}$ As options like cable and the internet developed, a neoliberal reaction questioned the necessity of must-carry rules and the fairness doctrine. Media options seemed endless, so why try to make any particular one fair or balanced? ${ }^{58}$

In the second decade of the new millennium, advancing computing capacity (and, more importantly, its social organization) has changed the landscape again. A sense of near-infinite plenitude inheres not merely in the internet as a whole, but also in the web giants constantly investing in the computing capacity needed to map large portions of it. When a service has hundreds of millions of users, the acceptance of certain rules for it starts to seem less

55 Chris Anderson, The Long Tail, Wired (Oct. 1, 2004, 12:00 PM), http://www. wired.com/wired/archive/12.10/tail.html.

56 Jack Balkin, The First Amendment Is an Information Policy, 41 HofsTRA L. Rev. 1, 7 (2012) ("[I]ndividual freedoms of speech, press, and assembly require an infrastructure of free expression.").

57 Red Lion Broad. Co. v. FCC, 395 U.S. 367 (1969), as received; cf. Barron, supra note 20.

58 John Blevins, Meet the New Scarcity: A First Amendment Framework for Regulating Access to the Digital Media Platforms, in Selected Works of John F. Blevins (2011), http://works.bepress.com/cgi/viewcontent.cgi?article=1004\&context=john_blevins ("[C]ourts should defer to access regulations of uncompetitive network-layer platforms such as broadband access infrastructure. Regulations of applicationlayer platforms such as search engines, by contrast, should be subjected to higher First Amendment scrutiny. . . . [because] different layers of modern digital networks have vastly distinct economic and technological characteristics."). Blevins believes that the old "scarcity" rationale behind Red Lion is obsolete, because "unique features of the Internet's architecture make application markets (including search engine markets) inherently competitive and contestable." Id. 
like overbearing state action than a virtual Magna Carta: rulers acceding to certain minimum standards of due process and inclusion..$^{59}$

Must-carry rules in this context are two removes from censorship as traditionally conceived. First, they are only adding information to a search platform: they are pro-speech. Adding one option does not automatically push out others. Second, they amount to an effort by one kind of sovereign to limit the power of another to censor. As Jeffrey Rosen observes:

Until recently, the person who had more power to determine who may speak and who may be heard around the world was not a president or king or Supreme Court Justice. She was Nicole Wong, who was deputy general counsel at Google until her recent resignation. Her colleagues called her "the Decider" ... . [because of her power] to decide what content goes up or comes down [on Google and YouTube throughout the world]. ${ }^{60}$

If a few legislatures decide to constrain the censorship power of Silicon Valley "deciders" in some ways, that regulation does not necessarily endanger freedom of expression. ${ }^{61}$

There are many ways that government could encourage more accountable intermediaries. The bevy of immunities Congress has granted to information location tools via the Digital Millennium Copyright $\mathrm{Act}^{62}$ and Communications Decency Act ${ }^{63}$

59 For the national analogy, see generally Lori Andrews, I KNOw Who You ARE AND I SAW What You Did (2011) (on the need for a social networking bill of rights); Rebecca MacKinnon, Consent of the Networked (2012) (extending the "platform as nation" metaphor); and Anupam Chander, Facebookistan, 90 N.C. L. REv. 1807, 1807 (2012) ("Who rules Facebookistan? Who makes the rules that govern the way a tenth of humanity connects on the Internet?").

60 Jeffrey Rosen, The Deciders, 80 Fordham L. Rev. 1525, 1536 (2012).

61 As legal scholar Dawn Nunziato observes, "Google, in its capacity both as the dominant Internet search engine and as the operator of its popular news aggregation site, has engaged in various acts of censorship." NunZIATO, supra note 17, at 12. In her book, Virtual Freedom, Nunziato mentions suspect decisions at Google News, Google AdWords, and the search engine generally. For example, Google seemed to retaliate against Inner-City Press by dropping the publication from Google News after it had questioned Google for failing to sign on to an anticensorship commitment known as The Global Compact. Id. at 13.

62 Digital Millennium Copyright Act, Pub. L. No. 105-304, 112 Stat. 2860 (1998) (codified as amended in scattered sections of 17 U.S.C.). See generally Rustad \& Koenig, supra note 29.

63 Communications Decency Act, Pub. L. No. 104-104, 110 Stat. 133 (1996) (codified as amended at scattered sections of 47 U.S.C.). See generally Rustad \& Koenig, supra note 29. 
might be conditioned on platforms adopting internal processes designed to give those entirely de-indexed some right to a fair hearing and explanation for the action. ${ }^{64}$ The critical point is to recognize the malleability of the new information infrastructure.

Admittedly, Google has won some lawsuits challenging its placement of websites in search results on free expression grounds. In Langdon v. Google, ${ }^{65}$ Langdon claimed that Google had a duty to carry his advertisements, which charged U.S. bureaucrats with corruption and China with committing atrocities. ${ }^{66}$ The district court dismissed the claim. ${ }^{67}$ For the Langdon court, Google's advertising decisions were tantamount to those made by a newspaper, and therefore regulation of them would be as suspect as the "right of reply" at issue (and rejected) in Miami Herald v. Tornillo ${ }^{68}$ However, the Miami Herald was merely one of hundreds of U.S. newspapers at the time of that decision. ${ }^{69}$

64 See generally Goss v. Lopez, 419 U.S. 565, 579 (1975) (noting that students who have suffered a loss or interference with a protected property interest "must be given some kind of notice and some kind of hearing"); Henry J. Friendly, Some Kind of Hearing, 123 U. PA. L. REv. 1267 (1975).

65 Langdon v. Google, Inc., 474 F. Supp. 2d 622 (D. Del. 2007).

66 Id. at 626; see also Frank Pasquale, Shaming Search Engines, Concurring OpinIons (Nov. 6, 2007, 4:57 PM), http://www.concurringopinions.com/archives/2007/11/ shaming_search.html (showing that congressional concern over search engines' complicity in the Chinese government's campaign against dissent was expressed in 2006 with the proposal of the Global Online Freedom Act). See generally Chris Langdon, Communist China Has Murdered Millions: Boycott China, Communist China Is EviL, http://soc.culture.irish.narkive.com/mvcyFwgI/forpaul-the-rabid-rabbit-communist-china-has-murdered-millions-boycott-china (last visited Feb. 1, 2016).

67 Langdon, 474 F. Supp. 2d at 634-35.

68 Miami Herald v. Tornillo, 418 U.S. 241 (1974); see Eric Goldman, "Must Carry” Lawsuit Against Search Engines — Langdon v. Google, Tech. \& MARKeting L. Blog (June 8, 2006, 12:46 PM), http://blog.ericgoldman.org/archives/2006/06/ must_carry_laws.htm:

Recall that from Miami Herald v. Tornillo, a statutory must-carry rule applied to newspapers violated the constitutional freedom of the press. Given the very specific justifications for tighter regulation of broadcasting, and that those bases have been held inapplicable to the Internet (see, e.g., Reno v. ACLU), I think (for these purposes) that search engines are more appropriately analogized to newspapers instead of broadcasters. Accordingly, I can't see how any judge could constitutionally order "must carry" relief here.

69 Pew Project for Excellence in Journalism, The State of the News Media 2004: An Annual Report on American Journalism, JourNALISM.ORG (2004), http://www. stateofthemedia.org/2004/newspapers-intro/audience/ (noting that in 2002 there were 1457 U.S. daily newspapers, after decades of consolidation in the industry). 
Google is a dominant search engine not only in the United States but in much of Europe and beyond, and plays a critical role for the inquisitive. To the extent that it is a media entity, it is closer to the situation of the firms in Red Lion and Turner than it is to the Miami Herald.$^{70}$ Its reach is far larger than that of the newspaper in Miami Herald. Its selection and arrangement of links comes far closer to the cable network or broadcaster's decision about what shows to program (where such entities, by and large, do not create the content they choose to air), than it does to a newspaper which mostly runs its own content and has cultivated an editorial voice (ala the Miami Herald). Finally, and most importantly, massive internet platforms must take the bitter with the sweet: if they want to continue avoiding liability for intellectual property infringement and defamation, they should welcome categorization as a conduit for speech, rather than speaker status itself.

\section{B. Antitrust and Competition Law}

Google is no stranger to competition regulation. One commentator has estimated that the company "officially violated antitrust laws in 10 different ways over 5 years." 71 The company's critics routinely critique its practices as anticompetitive. ${ }^{72}$ As of January 2012, it was under investigation in nine countries, the European Union, and some states in the United States. ${ }^{73}$ But

70 Turner Broad. Sys., Inc. v. FCC, 512 U.S. 622 (1994).

71 Scott Cleland, Google's Global Antitrust Rap Sheet - Google Now Has Violated Antitrust Laws in 10 Different Ways, Precursor Blog (Jan. 31, 2012, 6:42 PM), $\mathrm{http}: / /$ precursorblog.com/?q=content/googles-global-antitrust-rap-sheet-googlenow-has-violated-antitrust-laws-10-different-ways; see also Antitrust Regulators Raid Google's Offices in South Korea, BBC News (Sept. 7, 2011, 12:37 AM), http://www.bbc.co.uk/news/business-14816295.

72 See Benjamin Edelman, Bias in Search Results?: Diagnosis and Response, 7 Ind. J.L. \& Tech. 16, 30 (2011); Joshua Hazan, Stop Being Evil: A Proposal for Unbiased Google Search, 111 Mich. L. Rev. 789 (2013) (“Google's conduct does in fact violate $\S 2$ of the Sherman Act and $\S 5$ of the FTC Act."); Nathan Newman, The Cost of Lost Privacy: Search, Antitrust, and the Economics of Control of User Data 1 (Information Law Institute, NYU, Working Paper, 2013), http://papers.ssrn.com/sol3/papers.cfm?abstract_id=2265026 ("[W]hat is largely missed in analyses defending Google from antitrust action is how that ever expanding control of user personal data and its critical value to online advertisers creates an insurmountable barrier to entry for new competition.").

73 Press Release, European Comm'n, Antitrust: Commission Probes Allegations of Antitrust Violations by Google (Nov. 30, 2012), http://europa.eu/rapid/pressrelease_IP-10-1624_en.htm; Dan Levin, Google Faces Texas AG Inquiry, Settles 
in early January 2013, Google scored a major victory, as the Federal Trade Commission (FTC) agreed to drop nearly all of the most publicized part of its case against the company: allegations of biased and anticompetitive behavior in search results. Commissioner J. Thomas Rosch worried that Google may have been 'telling 'half-truths' — for example, that its gathering of information about the characteristics of a consumer is done solely for the consumer's benefit, instead of also to maintain a monopoly or near-monopoly position." "74 But the majority of the Commission decided unequivocally to end the investigation. They publicly justified the decision with little more than a page of assurances that FTC interviews and economic analyses had found little to no problematic behavior. ${ }^{75}$

Unmentioned in the decision, but perhaps influencing the result, was Google's would-be "trump card" argument against intervention: a constitutional claim that the First Amendment effectively foreclosed any robust remedies, such as requirements that Google alter search results to include links to competitors of its varied conglomeratized holdings. A Google filing written by Eugene Volokh and Donald Falk ${ }^{76}$ has made the "free expression" case for virtually unfettered discretion in the exercise of internet intermediaries' editorial judgment. The stakes of the legal strategy are high. If Google succeeds, just about any information age company ${ }^{77}$ could characterize its selection

Privacy Suit, Reuters: Tech. (Sept. 3, 2010, 8:01 PM), http://www.reuters.com/ article/2010/09/03/us-google-settlement-idUSN0312083220100903; Jessica Dye, Italy Launches Antitrust Probe of Google News, LAw 360 (Aug. 27, 2009, 2:19 PM), http://www.law360.com/corporate/articles/118735/italy-launchesantitrust-probe-of-google-news.

74 Concurring and Dissenting Statement of Commissioner J. Thomas Rosch Regarding Google's Search Practices, In the Matter of Google Inc., FTC File No. 1110163, at 1 n.1 (Jan. 3, 2013), https://www.ftc.gov/sites/default/files/documents/ public_statements/concurring-and-dissenting-statement-commissioner-j.thomasrosch-regarding-googles-search-practices/130103googlesearchstmt.pdf.

75 Statement of the Fed. Trade Comm'n Regarding Google's Search Practices, In the Matter of Google Inc., FTC File Number 111-0163 (Jan. 3, 2013), https:// www.ftc.gov/system/files/documents/public_statements/295971/130103goog lesearchstmtofcomm.pdf. The Commission's statement says: "The totality of the evidence indicates that, in the main, Google adopted [changes] improve the quality of its search results, and that any negative impact on actual or potential competitors was incidental to that purpose." But the Commission has not released details about the nature of that evidence, the types of tests it used, or the standards employed in them.

76 Volokh \& Falk, supra note 38, at 883-900.

77 Press Release, Fed. Trade Comm'n, FTC Joins Department of Justice and Consumer Financial Protection Bureau in Filing Brief Supporting the Constitutionality of 
and coordination of information as "searchy" and thus "speechy" enough to avoid regulation. ${ }^{78}$

Fortunately, neither courts nor regulators must accept a general theory of search as speech. It is an effort to impose a "one-size-fits-all" approach on multifarious phenomena. ${ }^{79}$ There is no generalized "free expression" exemption from competition laws for communication conduits or media firms - and to the extent that search engines mix both functions, they have never given an account of why that mixing should lead to even more protection from regulation than was enjoyed by the entities whose functions they meld. Indeed, there is a strong case for more regulation and watchdogging, since the vertical integration of content and conduit (along with horizontal conglomeratization accelerated by winner-take-all dynamics online) tends toward the creation of ever more powerful firms. ${ }^{80}$

Even in the United States, the Supreme Court has recognized that enforcement of the Sherman Act ${ }^{81}$ (a foundation of United States competition law), even in media contexts, can do as much to advance free expression as to restrict it. For example, in Associated Press v. United States, a newspaper association argued that it should be immune from certain aspects of competition law because of its expressive purpose. The Supreme Court rightly rejected that assertion:

The First Amendment, far from providing an argument against application of the Sherman Act, here provides powerful reasons to

the Fair Credit Reporting Act (May 8, 2012), https:/www.ftc.gov/news-events/ press-releases/2012/05/ftc-joins-department-justice-consumer-financial-protectionbureau.

78 Frank Pasquale, Search, Speech, and Secrecy: Corporate Strategies for Inverting Net Neutrality Debates, 29 Yale L. \& Pol'y Rev. Inter Alia (May 15, 2010, 10:15 AM), http://ylpr.yale.edu/inter_alia/search-speech-and-secrecy-corporatestrategies-inverting-net-neutrality-debates. For articles on the proper limits of the First Amendment, see Frederick Schauer, The Boundaries of the First Amendment: A Preliminary Exploration of Constitutional Salience, 117 HARV. L. Rev. 1765 (2004); and Robert C. Post, Recuperating First Amendment Doctrine, 47 Stan. L. Rev. 1249 (1995). In Frank Pasquale \& Oren Bracha, Federal Search Commission? Access, Fairness and Accountability in the Law of Search, 93 Cornell L. Rev. 1149, 1188-201 (2008), Oren Bracha and I applied their arguments (among others) in the new technological contexts created by search engines.

79 Andrei Broder, A Taxonomy of Web Search, ACM Sigir F., Fall 2002, at 3.

80 Ariel Ezrachi \& Maurice E. Stucke, Virtual Competition: The Promise and Perils of the Algorithm-Driven Economy (2016); Maurice Stucke and Alan Grunes, Big Data and Competition Policy (2016).

81 15 U.S.C. $\S 1$ (2012). 
the contrary. . . . Surely a command that the government itself shall not impede the free flow of ideas does not afford non-governmental combinations a refuge if they impose restraints upon that constitutionally guaranteed freedom. . . . Freedom to publish is guaranteed by the Constitution, but freedom to combine to keep others from publishing is not. . . . The First Amendment affords not the slightest support for the contention that a combination to restrain trade in news and views has any constitutional immunity. ${ }^{82}$

Admittedly, in the U.S. context, the First Amendment is often seen as a protection only from government action, not private initiative. But even U.S. courts are under no obligation to blind themselves to their First Amendment interpretations' effects on the general information environment. Virtually any government regulation will have direct or incidental impact on some entity's ability to "speak," and the determination of the line between proper and improper regulations, when regulations are challenged on free expression grounds, should depend not merely on the interests of the party bringing the suit, but on mature consideration of the general effects of the regulation.

Moreover, even some U.S. case law affirms a positive right to governmental intervention against the speech-constraining activity of private parties. U.S. courts have consistently held that, "when a crowd or individual threatens hostile action in response to a demonstration or speaker," the First Amendment "grants a positive right to the speaker: the local government must take action to protect the speaker against a hostile crowd. The courts do not allow local law enforcement to accede to a heckler's veto." $" 83$ Though U.S. courts have historically been extraordinarily suspicious towards positive rights framings of constitutional issues, the clash of private rights so evident in communicative contexts has forced them to recognize the importance of positive state action to promote truly free expression. This recognition should extend to digital contexts. For example, consider the possibility that massive internet platforms might secretly bias their news coverage in an election to promote one favored candidate. Successful legal action to require the disclosure of this pattern of behavior, as an unfair and deceptive trade practice, would improve the public sphere, not diminish it. Those who promote "more speech" as the solution to problems of media or intermediary bias in the democratic public sphere should welcome such disclosure requirements. ${ }^{84}$

82 Associated Press v. United States, 326 U.S. 1, 20 (1945).

83 Cheryl A. Leanza, Heckler's Veto Case Law as a Resource for Democratic Discourse, 35 Hofstra L. Rev. 1305, 1305 (2007).

84 Frank Pasquale, Search Neutrality as Disclosure and Auditing, BaLKINIZATION (Feb. 19, 2011), http://balkin.blogspot.com/2011/02/search-neutrality-as-disclosure-and.html. 
Both hostile crowds and monopolizing corporations can suppress speech. Laws guaranteeing public order respond to the first threat; competition law can address the second. For example, in Lorain Journal v. United States, a newspaper refused to deal with advertisers who advertised on its new competitor, a radio station..$^{85}$ The newspaper claimed that it had an unfettered right to choose its advertisers, but the Court disagreed. If business enterprises can get their core message across while respecting the intellectual property laws, so too should they be able to adequately communicate without trampling on the Sherman Act. ${ }^{86}$

The applicability of competition law to search engines should be even clearer than its applicability to pure media firms. There is a spectrum of plausibly "message-sending" entities; consider the range of messages plausibly "expressed" by each "author" in the following chart.

\section{Comparing the Expressiveness of Media and Corporations}

\begin{tabular}{|l|l|l|l|}
\hline & \multicolumn{2}{|c|}{ More Expressive } & \multicolumn{1}{c|}{ Less Expressive } \\
\hline Print & Newspaper article & $\begin{array}{l}\text { Chain of } \\
\text { newspapers }\end{array}$ & $\begin{array}{l}\text { Holding company owning } \\
\text { several chains of newspapers }\end{array}$ \\
\hline Radio & Song & $\begin{array}{l}\text { Chain of radio } \\
\text { stations }\end{array}$ & $\begin{array}{l}\text { Holding company owning } \\
\text { several chains of radio } \\
\text { stations }\end{array}$ \\
\hline Television & Program & Channel & Cable network \\
\hline
\end{tabular}

Were a government to require newspaper articles to express a particular point of view, that would be a violation of freedom of expression. Prohibiting one firm from owning more than thirty percent of newspaper chains or cable networks, though, has far less dire consequences for freedom of expression - and may well promote it. Similarly, basic rules about what advertisements a media firm must carry do not infringe on its primary function of delivering content. Note, too, that the chart above only covers the content and corporate organization of entities already recognized as media. To the extent dominant search engines, social networks, and other new media simply enable connections

85 Lorain Journal Co. v. United States, 342 U.S. 143, 155 (1951):

The publisher claims a right as a private business concern to select its customers and to refuse to accept advertisement from whomever it pleases. ... [But the] right claimed by the publisher is neither absolute nor exempt from regulation. Its exercise as a purposeful means of monopolizing interstate commerce is prohibited by the Sherman Act.

86 Sherman Act, 15 U.S.C. § 1 (2012). 
between audiences and content, they fall even further on the "less expressive" side of the spectrum schematized above.

Governments will continue to grapple with the free expression implications of ordering certain results to be included or excluded in search engine results pages. As they do so, they should remember that search engines, most of the time, share more in common with carriers and conduits than they do with media firms.$^{87}$ Moreover, to the extent that the media analogy is appropriate, it is not dispositive, as Turner Broadcasting learned in the context of its illfated facial challenge to "must-carry" regulations, and the Lorain Journal and Associated Press learned in the competition law context.

\section{Privacy Laws}

Once upon a time, it was plausible to strictly distinguish between information collection by private firms, and that done by the government. Libertarians in particular expressed deep suspicion of the latter, and tended to view the former as a form of free inquiry, deserving whatever constitutional protections are afforded to speech by human persons. However, scholars have shown that the government often uses private databases to gather data it is itself forbidden from collecting. ${ }^{88}$ After the Snowden revelations of pervasive government hacking of (or collaboration with) massive technology firms, the stakes of so-called "private" information gathering are even clearer. There is no clear line between corporate and governmental data gathering.

The Snowden revelations also suggested another complication of longstanding theoretical assumptions about the divide between public and private. Certain parts of the state, such as the Commission Nationale de l'Informatique et des Libertés (CNIL) in France or FTC in the United States, can stop or limit data acquisition and transfer. Others, primarily in the security and intelligence sectors, urge the expansion and intensification of surveillance. One major reason persons fail to speak out or protest is because they are afraid of their words coming back to haunt them. ${ }^{89}$ This fear is not unfounded: recent

87 Frank Pasquale, Internet Nondiscrimination Principles: Commercial Ethics for Carriers and Search Engines, 2008 U. Chi. Legal F. 263, 289 (directly analogizing the two commercial entities).

88 Chris Jay Hoofnagle, Big Brother's Little Helpers: How ChoicePoint and Other Commercial Data Brokers Collect and Package Your Data for Law Enforcement, 29 N.C. J. Int'L L. \& Com. Reg. 595 (2003); Jon D. Michaels, All the President's Spies: Private-Public Intelligence Partnerships in the War on Terror, 96 CALIF. L. REv. 901 (2008).

89 Neil Richards, Intellectual Privacy: Rethinking Civil Liberties in the Digital Age (2015); Daniel Solove, Nothing to Hide: The False Tradeoff Between Privacy AND SECURITY (2011). 
surveillance abuses have uncovered frequent government monitoring of core political communication. ${ }^{90}$ Therefore, some quantum of privacy is a sine qua non of free expression rights worth having. The instrumentalities of the state that guarantee such privacy are part of the infrastructure of free expression. The "private" firms that defy or evade those guardians of privacy are just as surely undermining the infrastructure of free expression as the surveillance state that has monitored, and will continue to monitor, the data gathered by private firms. $^{91}$

The integration of state and private surveillance has cast Eugene Volokh's effort to characterize privacy protections as the "troubling right to stop others from speaking about you" in a new light. ${ }^{92}$ Given the rising power of algorithmic classifications based on big data, predictive analytics, and machine learning programs seamlessly integrating corporate and state information, threats to personal reputation or liberty appear less as speech than as menacing classifications. "Relational surveillance," based not only on state-gathered data but also the observations of a private apparatus far more invasive and intrusive, may run afoul not merely of the Fourth Amendment, but also of the First Amendment. ${ }^{93}$ To the extent that privacy laws require data deletion or compartmentalization that frustrates such surveillance, they are likely to do as

90 Frank Pasquale, We Must Confront the Recent Surveillance Abuses to Develop Better Policy Moving Forward, LSE BLog (Jan. 23, 2014), http://blogs.lse. ac.uk/usappblog/2014/01/23/we-must-confront-the-recent-surveillance-abusesto-develop-better-policy-moving-forward/.

91 Bernard Harcourt, Law and Digital Ascesis, Concurring Opinions (Mar. 17, 2016), http://concurringopinions.com/archives/2016/03/law-and-digital-ascesis. html; Frank Pasquale, A Social Theory of Surveillance, Concurring OPInIONS (Mar. 15, 2016), http://concurringopinions.com/archives/2016/03/a-socialtheory-of-surveillance.html.

92 Eugene Volokh, Freedom of Speech and Information Privacy: The Troubling Implications of a Right to Stop People from Speaking About You, 52 StAn. L. REv. 1049, 1051 (2000). Neil Richards has dissected the flaws in Volokh's Lochneresque effort to reduce the complex societal dynamics of fair data practices to Hohfeldian trump cards held by individuals and corporations. See Neil M. Richards, Reconciling Privacy and the First Amendment, 52 UCLA L. Rev. 1149, 1150 (2005).

93 Katherine J. Strandburg, Freedom of Association in a Networked World: First Amendment Regulation of Relational Surveillance, 49 B.C. L. REv. 741 (2008):

Despite the rising importance of digitally mediated association, current Fourth Amendment and statutory schemes provide only weak checks on government. The potential to chill association through overreaching relational surveillance is great. ... [T] he First Amendment's freedom of association guarantees can and do provide a proper framework for regulating relational 
much to support fundamental values of free expression of persons, as they are to undermine the rights of corporations as researchers or archivists of data. ${ }^{94}$

Individuals' ability to learn more about the world is also enabled by targeted restrictions on the collection and sharing of information by large firms. A person might hesitate to join a mental illness support group on Facebook, once she is aware that a data miner might later use the data generated by that membership in myriad, unforeseeable contexts. State restrictions on the sale of such data enable her rights of free association and inquiry, even if they come at the expense of asserted corporate prerogatives to perfectly "know" potential customers, and speak about and to them. Rather than framing the issue as one of privacy versus free expression, it is more proper to see this as a dispute over rival claims of free expression - where privacy interests weigh heavily on one side.

The technological tools for matching digital records are staggering. State restrictions on the use of that data (or other forms of tracking) can be an important step toward giving individuals a chance to form and express opinions and affiliations in peace — without fearing an endlessly ramifying series of classifications made and opportunities possibly denied, on account of faceless and secretive data miners. One legal expert recently warned that employers "may develop complex scoring algorithms based on electronic health records to determine which individuals are likely to be high-risk and high-cost workers." $" 95$

surveillance and suggests how these guarantees might apply to particular forms of analysis of traffic data.

94 As Danielle Citron and I have documented, this kind of surveillance has already had troubling chilling effects for political groups on both left and right. Danielle Keats Citron \& Frank Pasquale, Network Accountability for the Domestic Intelligence Apparatus, 62 Hastings L.J. 1441, 1459-60 (2011). Dan Solove has also argued convincingly that "there are doctrinal, historical, and normative justifications for developing" First Amendment-based limits on the "countless searches and seizures involving people's private papers, the books they read, the websites they surf, and the pen names they use when writing anonymously." Daniel Solove, The First Amendment as Criminal Procedure, 82 N.Y.U. L. REv. 112, 112 (2007). Marc Jonathan Blitz has explored the intersection of free speech and privacy values in Stanley v. Georgia, 394 U.S. 557 (1969), a case that guaranteed First Amendment protection for obscene materials "when read or viewed by a person in her own home." See Marc Jonathan Blitz, Stanley in Cyberspace: Why the Privacy Protection of the First Amendment Should Be More Like That of the Fourth, 62 Hastings L.J. 357, 359 (2010). Paul Schwartz paved the way for much of this work in Paul M. Schwartz, Privacy and Democracy in Cyberspace, 52 Vand. L. Rev. 1607 (1999).

95 Sharona Hoffman, Employing E-Health: The Impact of Electronic Health Records on the Workplace, 19 Kan. J.L. \& PuB. PoL'y 409, 422 (2010). Roland Behm 
The state has a strong interest in delaying the dawn of a brave new world of secret characterizations until far more robust infrastructures ensuring data accuracy and accountability are developed. Such restrictions are meant just as much to enable and empower the speech of citizens, as they are to restrict information flows among corporate actors (and the punitive or security arms of the state that rely on their data gathering).${ }^{96}$

\section{Conclusion: Toward a Social Theory of Free Expression in an Era of Platform Capitalism}

At a 2012 Diane von Furstenburg fashion show, models wore "Google Glasses" as they walked down the runway, filming the audience that observed them. The glasses contained not only a tiny camera, but also a screen that could project information for their wearers, like a crawl at the bottom of a cable news program. Synced to face-recognition technology, the glasses might give details on the name, profession, awards, net worth, and criminal record of any face in the crowd. The "faceprint" is the new fingerprint. The "augmented reality" devices promised to make their wearers "laser focused, walking encyclopedias." ${ }^{97}$ Media outlets lapped up the story, titillated by yet another facet of science fiction about to become commercial fact.

Far less salient in their eyes were the concerns raised by a 2005 honors thesis, Through the Google Goggles: Sociopolitical Bias in Search Engine Design, by Alejandro M. Diaz. ${ }^{98}$ Diaz described how "designs for search

has also documented the intrusion of mental health-driven characterizations into job applicant scoring used by major corporations. Roland Behm, What Are the Issues?, Employment Testing: Failing to Make the Grade (July 20, 2013), http://employmentassessment.blogspot.com/2013/07/what-are-issues.html.

96 For an account of the interconnections between one such firm and the U.S. surveillance apparatus, see Julian Assange, When Google Met Wikileaks (2014).

97 Nathan Shedroff \& Christopher Noessel, Make It So: Interaction Design LeSSONS From Science Fiction 176 (2012). But see Elise Ackerman, Why Smart Glasses Might Not Make You Smarter: A Q\&A with Wearable-Computer Pioneer Steve Mann, IEEE: SPECTRUM (Dec. 31 2012), http://spectrum.ieee.org/consumerelectronics/gadgets/why-smart-glasses-might-not-make-you-smarter.

98 Alejandro Diaz, Through The Google Goggles: Sociopolitical Bias in Search Engine Design (May 2005) (unpublished M.A. thesis, Stanford University Program on Science, Technology \& Society); see also Alejandro M. Diaz, Through the Google Goggles: Sociopolitical Bias in Search Engine Design, in Web Search 11 (Amanda Spink \& Michael Zimmer eds., 2008). 
technologies encode certain values about what sort of content is 'important,' 'relevant,' or 'authoritative,'" and chronicled case after case where Google's decisions implicated such values. Even as early as 1999, a growing literature was questioning the political and ethical values underlying the search systems that were then beginning to make sense of the internet. Diaz's evocative metaphor, "Google Goggles," suggests that the firm's glasses, like its search engines, may not only "augment" reality, but also distort it, bias it, render it in certain preapproved corporate directions, and blind users to more critical takes.

When massive platforms combine the functions of conduits, content providers, and data brokers, analogies from old free expression cases quickly fall apart. Too many discussions of the expressive dimensions of new media are nevertheless moored in murky doctrinal categories, reifications, and inapt historical analogies that do more to obscure than reveal the true stakes of disputes. It is time to think beyond the old categories and to develop a new way of balancing dominant platforms' rights and responsibilities. Sometimes, that will require the translation of old principles of media regulation (like rules against stealth marketing) to new contexts. In other cases, litigation will be needed to stop dominant platforms from abusing their power online. Platforms should also acknowledge their de facto role as public forums and quasi-judicial law interpreters, even if they resist taking on all the de jure responsibilities such roles imply for state actors.

Unfortunately, the frequent invocation of "free expression" now appears to be little more than a facet of Silicon Valley public relations. ${ }^{99}$ Companies like Twitter and Facebook are quick to take the credit when their platforms are part of movements, but trivialize user rights in their own governance. It is almost as if the platforms see themselves as virtual worlds, whose users have essentially accepted (via terms of service) near-absolute sovereignty of corporate rulers. ${ }^{100}$

At their best, platforms recognize that such sovereignty comes with responsibilities as well as rights. The power to rank is the power to make certain public impressions permanent, and others fleeting. As platforms gain commercial, political, and cultural influence, their "often opaque technology

99 Katherine Losse, The Boy Kings: A Journey into the Heart of the Social NETWORK (2012).

100 James Grimmelmann, Virtual World Feudalism, 118 Y ale L.J. Pocket Part 126, 128 (2009) (arguing that in the digital feudalism of virtual worlds, the software developer "is both the grantor who makes the grant and the law which protects it”) (quoting S.F.C. Milsom, Historical Foundations of the Common Law 104 (1st ed. 1969)). 
of ranking becomes kingmaker in new venues."101 The question now is whether the state (and companies themselves) will make these processes more comprehensible, fair, transparent, and open to critical analysis by the publics they affect.

101 Halavais, supra note 51, at 85. 
